\title{
Synthesis and Immunoadjuvant Activity of Acylamino Analogs of $\mathrm{N}$-Acetylmuramoyl-L-alanyl-D-isoglutamine
}

\author{
Hiroyuki OKumura, Kei-ichi Kamisango, Ikuo SAIKI, \\ Yoshiro Tanio, Ichiro Azuma, Makoto Kiso, ${ }^{*}$ \\ Akira HASEGAWA* and Yuichi YAMAMURA** \\ Institute of Immunological Science, Hokkaido University, \\ Sapporo 060, Japan \\ * Department of Agricultural Chemistry, Gifu University, \\ Kakamigahara, Gifu 504, Japan \\ **Osaka University, Suita, Osaka 565, Japan \\ Received September 9, 1981
}

\begin{abstract}
A variety of long-chain fatty acylamino analogs of $N$-acetylmuramoyl-L-alanyl-D-isoglutamine (MDP), such as $N$-(acyl)muramoyl-dipeptides (1) and $N$-acetyl-6-(acylamino)-6-deoxymuramoyldipeptides (2), were synthesized to examine their immunological activities. All the $N$ (acyl)muramoyl-L-alanyl-D-isoglutamines (1) were active as adjuvant on the induction of delayedtype hypersensitivity to azobenzenearsonate- $N$-acetyl-L-tyrosine in guinea pigs. $N$-(3-Hydroxy-2tetradecyloctadecanoylamino)muramoyl-L-alanyl-D-isoglutamine (1d) and $N$-acetyl-6-deoxy-6-(3hydroxy-2-docosylhexacosanoylamino)muramoyl-L-alanyl-, -L-valyl-, and -L-seryl-D-isoglutamines (2) showed antitumor activity by suppressing tumor (Meth-A fibrosarcoma) growth in syngeneic BALB $/ c$ mice.
\end{abstract}

The adjuvant-active minimal structure of bacterial cell wall peptidoglycans was established to be $N$-acetylmuramoyl-L-alanyl-Disoglutamine ${ }^{2,3)}$ (MDP: 1a), and the details of immunological properties were investigated. The relationship between the chemical structures and immunological activities of MDP derivatives and the analogs were examined by many groups. ${ }^{4)}$ It was found ${ }^{5 \sim 7)}$ that the L-alanine residue in MDP could be replaced by other suitable amino acids such as L-valine, L-serine, L-methionine or L-glutamine without decreasing the activity. We have demonstrated that the sugar skeleton in MDP is not restricted to 2-acetamido-2-deoxy-D-glucose. It can be replaced by 2-acetamido-2-deoxy-D-mannose and -D-galactose, D-glucose and 2-acetamido6-amino- and -6-(acylamino)-2,6-dideoxy-Dglucose, while retaining the activity. ${ }^{8 \sim 13)}$

On the other hand, some of the lipophilic MDP derivatives, i.e., $\quad N$-acetyl-6- $O$ - "mycoloyl"-muramoyl-dipeptide and $\mathrm{N}$ acetyl-6- $O$-quinonyl-muramoyl-dipeptide, were shown to have not only adjuvant activity, but also antitumor activity. ${ }^{14 \sim 16)}$ In these compounds, the hydroxy group on C- 6 of the carbohydrate moiety in MDP is esterified with "mycolic" acid or synthetic long-chain fatty acid.

Recently, we have found that the 2-amino group of the carbohydrate moiety in MDP can be acylated by myristoyl, stearoyl, 3-hydroxymyristoyl and 3-hydroxystearoyl groups ${ }^{11}$ instead of the acetyl group without decreasing the activity. In this paper, we describe the synthesis and immunological activities of $\mathrm{N}$ (acyl)muramoyl-dipeptides $(\mathbf{1 b} \sim \mathbf{1 f})$ and $\mathrm{N}$ acetyl-6-(acylamino)-6-deoxymuramoyldipeptides $(\mathbf{2 A} \sim \mathbf{2 C})$ bearing other long-chain fatty-acyl residues as the lipophilic group. We also discuss the effect of the alkyl-chain length of the $\mathrm{N}$-acyl moiety for the adjuvant activity. 


\section{RESULTS AND DISCUSSION}

\section{Chemical synthesis}

We used tetracosanoic, 2-tetradecylhexadecanoic, 3-hydroxy-2-tetradecyloctadecanoic, 3-hydroxy-2-docosylhexacosanoic, and mycolic acids, ${ }^{14,15)}$ as the long-chain fatty acid.

Brief hydrogenolysis of benzyl 2-(benzyloxycarbonylamino)-2-deoxy-4,6- $O$-isopropylidene- $\alpha$-D-glucopyranoside ${ }^{1)}$ (3) in the presence of $10 \%$ palladium-carbon catalyst, and subsequent treatment with $N$-(tetracosanoyloxy)succinimide or $N$-(2-tetradecylhexadecanoyloxy)succinimide afforded benzyl 2-deoxy-4,6- $O$-isopropylidene-2-(tetracosanoylamino)- and -2-(tetradecylhexadecanoylamino)- $\alpha$-D-glucopyranosides

$(4 \mathbf{b}$, c), respectively. The $N$-acyl derivatives $\mathbf{4 b}$ and $\mathbf{4 c}$ were condensed with L-2-chloropropanoic acid in the presence of sodium hydride, to give benzyl 3-O-(D-1-carboxyethyl)-2-deoxy-4,6-O-isopropylidene-2(tetracosanoylamino)- and -2-(2-tetradecylhexadecanoylamino)- $\alpha$-D-glucopranosides $(6 \mathbf{b}, \mathbf{c})$. In order to introduce $\alpha$-branched $\beta$ hydroxylated fatty acids (mycoloyl type), compound 3 was first condensed with L-2chloropropanoic acid to afford benzyl 2(benzyloxycarbonylamino)-3-O-(D-1-carboxyethyl)-2-deoxy-4,6- $O$-isopropylidine- $\alpha$-Dglucopyranoside (5), which was converted, by selective hydrogenolysis of the benzyl- oxycarbonyl group and subsequent treatment with $N$-(3-hydroxy-2-tetradecyloctadecanoylor -2-docosylhexacosanonyl-oxy)succinimide or $N$-(mycoloyloxy)succinimide, into the corresponding $\mathrm{N}$-fatty acyl, 3-O-(D-1-carboxyethyl) derivatives $(\mathbf{6 d} \sim \mathbf{f})$. Compounds $\mathbf{6 b} \sim \mathbf{f}$ were coupled with L-alanyl-D-isoglutamine benzyl ester, using dicyclohexylcarbodiimide and $N$-hydroxysuccinimide as the activating agents, to yield the protected $N$-(acyl)muramoyl-dipeptides $(\mathbf{7 b} \sim \mathbf{f})$. Hydrolytic removal of the 4,6-O- isopropylidene group from com-

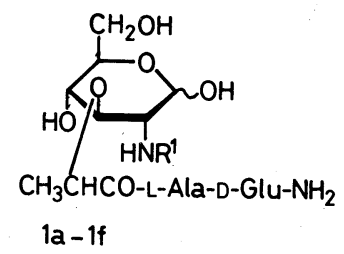

$$
\begin{aligned}
\text { a } R^{\prime}= & \mathrm{COCH}_{3} \\
\text { b } R^{\prime}= & \mathrm{CO}\left(\mathrm{CH}_{2}\right)_{22} \mathrm{CH}_{3} \\
\text { C } R^{\prime}= & \underset{\mathrm{CO}}{\mathrm{CH}\left(\mathrm{CH}_{2}\right)_{13} \mathrm{CH}_{3}} \\
& \left(\mathrm{CH}_{2}\right)_{13} \mathrm{CH}_{3}
\end{aligned}
$$

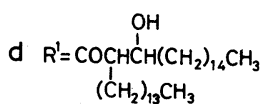

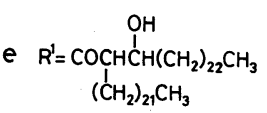$$
\text { f } R^{\prime}=\text { Mycoloyl }
$$

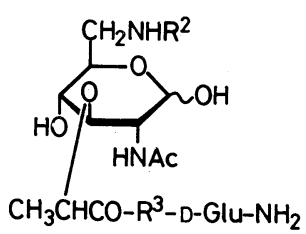
$\mathrm{R}^{2}=\underset{\substack{\mathrm{O} \\ \mathrm{I}}}{\mathrm{COCH}\left(\mathrm{CH}_{2}\right)_{22} \mathrm{CH}_{3}}$
A $R^{3}=L-A l a$
B $R^{3}=L-V a l$

$2 A-2 C$
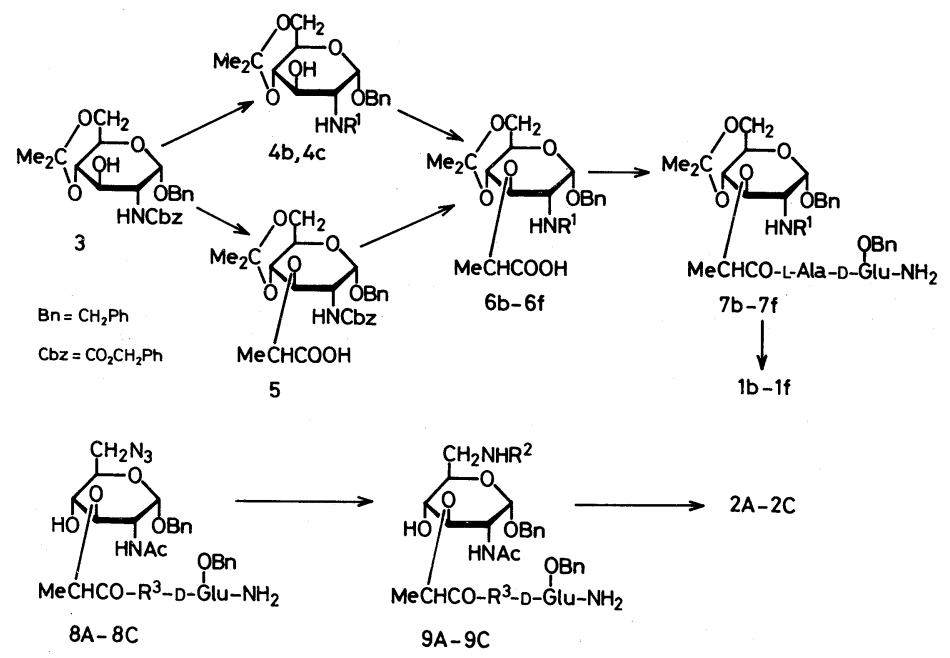
pounds $7 \mathbf{b} \sim \mathbf{f}$ with $80 \%$ acetic acid, followed by hydrogenolysis in the presence of palladium black catalyst, gave the desired $N$ (acyl)muramoyl-L-alanyl-D-isoglutamines $(\mathbf{1 b} \sim \mathbf{f})$.

For the synthesis of the 6-acylamino analogs, we employed benzyl 2-acetamido-6azido-2,6-dideoxy-3-O-(D-2-propanoyl-Lalanyl-, -L-valyl-, and - $O$-benzyl-L-seryl-Disoglutamine benzyl ester)- $\alpha$-D-glucopyranosides $^{11)}(\mathbf{8 A} \sim \mathbf{8 C})$ as the synthetic intermediates. Selective reduction of the azide group in $\mathbf{8 A} \sim \mathbf{8 C}$, and subsequent condensation of the 6-amino compounds with $\mathrm{N}$-(3hydroxy-2-docosylhexacosanoyloxy)succinimide, gave the acylated derivatives $(9 \mathrm{~A} \sim 9 \mathrm{C})$. The protecting groups of 9A $\sim 9 \mathrm{C}$ were removed by hydrogenolysis with palladium black catalyst to afford $N$-acetyl-6deoxy-6-(3-hydroxy-2-docosylhexacosanoylamino)muramoyl-L-alanyl-, -L-valyl-, and -Lseryl-D-isoglutamines $(\mathbf{2 A} \sim \mathbf{2 C})$.

\section{Adjuvant and antitumor activities}

The adjuvant activity of the $N$-(acyl)muramoyl-L-alanyl-D-isoglutamines $\quad(\mathbf{1 b} \sim \mathbf{1 f})$ was examined on the induction of delayedtype hypersensitivity to azobenzenearsonate- $N$-acetyl-L-tyrosine (ABA-tyrosine) in guinea pigs. As shown in Table I, all of the compounds tested were found to have adjuvant activity similar to or more potent than that of MDP. It was also found that the short-chain acylamino derivatives of MDP, e.g., $N$-(myristoyl, stearoyl, 3-hydroxymyristoyl or 3-hydroxystearoyl)muramoyl-Lalanyl-D-isoglutamine, exhibit potent activity. ${ }^{1)}$ Recently, we reported the adjuvant activity of $N$-acetyl-6-(acylamino)-6-deoxymuramoyl-dipeptides. ${ }^{12)}$ In these compounds, $\mathrm{N}$-acetyl-6-deoxy-6-(mycoloylamino)muramoyl-L-alanyl-D-isoglutamine had a distinct, but weak, adjuvant activity as compared to that of 6-acetamido or 6-(stearoylamino) analog of MDP in the same immune system. On the other hand, $N$-(mycoloyl)muramoylL-alanyl-D-isoglutamine (1f), which was mycoloylated at the C-2 amino group of the carbohydrate moiety in MDP, showed potent activity even at a dose of $33 \mu \mathrm{g}$. The results suggest that attachment of the long-chain fatty acyl moiety to the C-2 amino group is

Table I. Adjuvant Activity of $N$-(ACYl)muramoyl-DipePtides ON the Induction of Delayed-type Hypersensitivity in Guinea Pigs ${ }^{a}$

\begin{tabular}{|c|c|c|c|c|}
\hline Compound & $\begin{array}{c}\text { Dose }^{b} \\
(\mu \mathrm{g})\end{array}$ & $\begin{array}{c}\text { Skin reaction } \\
\text { with ABA-BSA } \\
\text { at } 24 \mathrm{hr}\end{array}$ & $\begin{array}{l}\text { Dose } \\
(\mu \mathrm{g})\end{array}$ & $\begin{array}{c}\text { Skin reaction } \\
\text { with ABA-BSA } \\
\text { at } 24 \mathrm{hr}\end{array}$ \\
\hline & Expt.I & \multicolumn{3}{|c|}{ Expt. II } \\
\hline $1 \mathbf{a}(\mathrm{MDP})$ & 100 & $24.6 \pm 1.0$ & 10 & $17.4 \pm 0.7$ \\
\hline $1 \mathrm{~b}$ & 160 & $21.4 \pm 1.4$ & & $\mathrm{ND}^{d}$ \\
\hline 1c & 180 & $22.1 \pm 0.8$ & 18 & $22.9 \pm 1.8$ \\
\hline 1d & 200 & $22.4 \pm 0.8$ & 20 & $15.0 \pm 0.7$ \\
\hline $1 \mathrm{e}$ & 230 & $23.9 \pm 0.5$ & 23 & $20.4 \pm 0.7$ \\
\hline 1f & 330 & $23.6 \pm 1.0$ & 33 & $24.6 \pm 1.3$ \\
\hline Control: & \multirow{2}{*}{\multicolumn{2}{|c|}{0}} & & \multirow[t]{2}{*}{$(4.0 \pm 0)^{e}$} \\
\hline ABA-tyrosine in FIA & & & & \\
\hline
\end{tabular}

a Four Hartley guinea pigs were immunized in four footpads with $50 \mu \mathrm{g}$ of azobenzenearsonate- $N$-acetyl-Ltyrosine (ABA-tyrosine) in Freund incomplete adjuvant (FIA) containing each compound. After 2 weeks, skin tests were performed with $100 \mu \mathrm{g}$ of ABA-bovine serum albumin (ABA-BSA), and the skin reactions were measured 24 and $48 \mathrm{hr}$ after intradermal injection of the test antigen.

$b$ The doses of each compound are dependent on the molecular weights.

$c$ The data indicate the average diameter $(\mathrm{mm}) \pm$ the standard error of the skin reaction (induration) of four guinea pigs at $24 \mathrm{hr}$.

d ND, not done.

e Only faint erythema was observed. 
Table II. Tumor Suppressive ACtivity of Synthetic ACylamino Analogs of MDP ${ }^{a}$

\begin{tabular}{lccc}
\hline Compound & $\begin{array}{c}\text { Dose } \\
(\mu \mathrm{g})\end{array}$ & $\begin{array}{c}\text { No. of tumor-free mice/ } \\
\text { No. of mice treated }\end{array}$ & $\begin{array}{c}\text { No. of tumor-free mice/ } \\
\text { No. of mice reinoculated }\end{array}$ \\
\hline $\mathbf{1 c}$ & 100 & $0 / 10$ & \\
$\mathbf{1 d}$ & 100 & $6 / 10^{* d}$ & $6 / 6^{*}$ \\
$\mathbf{1 e}$ & 100 & $3 / 10$ & \\
$\mathbf{1 f}$ & 100 & $0 / 10$ & $9 / 9^{*}$ \\
$\mathbf{2 A}$ & 100 & $9 / 11^{*}$ & $4 / 5^{*}$ \\
$\mathbf{2 B}$ & 100 & $4 / 10^{* *}$ & $0 / 10$ \\
$\mathbf{2 C}$ & 100 & $5 / 10^{*}$ & \\
Control & & $0 / 10$ & \\
\hline
\end{tabular}

a A mixture of tumor cells (Meth-A: $2 \times 10^{5}$ ) and each compound suspended in phosphate-buffered saline (PBS) was inoculated intradermally into the flank of BALB $/ c$ female mice. Four weeks later, tumor-free mice were reinoculated intradermally with the same tumor cells $\left(2 \times 10^{5}\right)$.

$b$ Results at 4 weeks after inoculation of the mixture.

c Results at 2 weeks after reinoculation.

${ }^{d}$ Statistical analysis by $\chi^{2}$-test of each group compared to control $* p<0.01, * * p<0.05$.

more favorable than that at C-6 substituent (amino group) for the development of the adjuvant activity.

We have demonstrated that the lipophilic derivatives of MDP, e.g., 6-O-"mycoloyl"MDP or 6-O-quinonyl-MDP, display antitumor activity on the suppression of tumor growth. ${ }^{14 \sim 16)}$ Therefore we examined the tumor (Meth-A fibrosarcoma) suppressive activity of $N$-(acyl)muramoyl-dipeptides $(\mathbf{1 c} \sim \mathbf{1 f})$ and $N$-acetyl-6-(acylamino)-6-deoxymuramoyl-dipeptides $(\mathbf{2 A} \sim \mathbf{2 C})$ in syngeneic $\mathrm{BALB} / c$ female mice. As summarized in Table II, compounds $\mathbf{1 d}, \mathbf{2 A}, \mathbf{2 B}$ and $\mathbf{2 C}$ were shown to be significantly active $\left(p<0.05\right.$ by $\chi^{2}$-test $)$ on the suppression of tumor growth. Recently, it was also observed that $N$-acetyl-6- deoxy-6(nocardomycoloylamino)muramoyl-L-alanyl-, and -L-seryl-D-isoglutamines showed potent tumor-suppressive activity in the same system. Moreover, the tumor-free mice rejected the same tumor cells after intradermal transplantation into the other site of the mice. These results indicate that compounds $\mathbf{1 d}, \mathbf{2 A}$ and $\mathbf{2 C}$ possess the antitumor activity based on a immune reaction to the transplantable tumor.

\section{EXPERIMENTAL}

Chemical synthesis. Melting points were determined with a Yamato micro melting-point apparatus and are uncorrected. Specific rotations were determined with a Union PM-101 polarimeter, and IR spectra were recorded with a Shimadzu IR-27G spectrophotometer. NMR spectra were recorded at $60 \mathrm{MHz}$ with a Hitachi R-20B spectrometer. Preparative chromatography was performed on silica gel (Merck Co.; 200 mesh) with the solvent systems specified. Evaporations were coducted in vacuo.

Benzyl 2-deoxy-4,6-O-isopropylidene-2-(tetracosanoylamino)- $\alpha$-D-glucopyranoside (4b). To a solution of benzyl 2-(benzyloxycarbonylamino)-2-deoxy-4,6- $O$-isopropylidene- $\alpha$-D-glucopyranoside ${ }^{1)}(3)(2.0 \mathrm{~g})$ in $\mathrm{MeOH}(15 \mathrm{ml})$ was added $10 \% \mathrm{Pd} / \mathrm{C}$ catalyst $(0.5 \mathrm{~g})$, and hydrogen was bubbled through, with stirring, for $1 \mathrm{hr}$ at room temperature, the course of the reaction being monitored by TLC. The catalyst was filtered off, and the filtrate was evaporated below $40^{\circ} \mathrm{C}$. To a solution of the residue in 1,4dioxane $(20 \mathrm{ml})$ was added $N$-(tetracosanoyloxy)succinimide $\left(\mathrm{mp} 101.5^{\circ} \mathrm{C}\right)(2.5 \mathrm{~g})$ which was prepared from tetracosanoic acid by $N$-hydroxysuccinimide-dicyclohexylcarbodiimide method, and the mixture was stirred for $5 \mathrm{hr}$ at room temperature, and then evaporated. The residue was chromatographed on a column of silica gel $(100 \mathrm{~g})$ with $100: 1 \mathrm{CHCl}_{3}-\mathrm{MeOH}$ to give $4 \mathbf{b}(2.21 \mathrm{~g}$, $74 \%)$ as crystals, $\mathrm{mp} 94^{\circ} \mathrm{C},[\alpha]_{\mathrm{D}}^{20}+58.3^{\circ}\left(c=0.6, \mathrm{CHCl}_{3}\right)$; IR $v_{\max }^{\mathrm{KBr}} \mathrm{cm}^{-1}: 3400(\mathrm{OH}), 3320(\mathrm{NH}), 2920$ and 2850 $\left(\mathrm{CH}_{2}, \mathrm{CH}_{3}\right), 1640$ and 1530 (amide), $850\left(\mathrm{Me}_{2} \mathrm{C}\right)$, and 720 and 690 (phenyl); NMR $\delta_{\mathrm{Me}_{4} \mathrm{Si}}^{\mathrm{CDCl}_{3}}: 0.90\left(3 \mathrm{H}, \mathrm{CH}_{3}\right), 1.30$ $\left(42 \mathrm{H}, 21 \mathrm{CH}_{2}\right), 1.47$ and $1.56\left(6 \mathrm{H}, 2 \mathrm{~S}, \mathrm{Me}_{2} \mathrm{C}\right), 3.27(1 \mathrm{H}, \mathrm{bs}$, $\mathrm{OH}), 4.50$ and $4.83\left(2 \mathrm{H}, 2 \mathrm{~d}, J_{\mathrm{gem}}=12.0 \mathrm{~Hz}, \mathrm{OCH}_{2} \mathrm{Ph}\right)$, $4.98\left(1 \mathrm{H}, \mathrm{d}, J_{1,2}=3.7 \mathrm{~Hz}, \mathrm{H}-1\right), 5.97\left(1 \mathrm{H}, \mathrm{d}, J_{2, \mathrm{NH}}=\right.$ $8.0 \mathrm{~Hz}, \mathrm{NH})$ and $7.45(5 \mathrm{H}, \mathrm{s}, \mathrm{Ph})$. Anal. Found: C, 72.66; $\mathrm{H}, 10.49 ; \mathrm{N}, 2.22$. Calcd. for $\mathrm{C}_{40} \mathrm{H}_{69} \mathrm{NO}_{6}: \mathrm{C}, 72.79 ; \mathrm{H}$, $10.54 ; \mathrm{N}, 2.12 \%$. 
Benzyl 2-deoxy-4,6-O-isopropylidene-2-(2-tetradecylhexadecanoylamino)- $\alpha-\mathrm{D}-$ glucopyranoside (4c). Selective hydrogenolysis of $3(500 \mathrm{mg})$ in $\mathrm{MeOH}(10 \mathrm{ml})$ in the presence of $10 \% \mathrm{Pd} / \mathrm{C}$ catalyst $(200 \mathrm{mg})$ was carried out according to the procedure described above. To a solution of the amino derivative thus obtained, in 1,4-dioxane (5 ml), was added $N$-(2-tetradecylhexadecanoyloxy)succinimide $\left(\mathrm{mp} 50 \sim 51^{\circ} \mathrm{C}\right)(740 \mathrm{mg})$ which was prepared from 2-tetradecylhexadecanoic acid, and the mixture was stirred overnight at room temperature, and then evaporated. The residue was chromatographed on a column of silica gel $(20 \mathrm{~g})$ with $100: 1 \mathrm{CHCl}_{3}-\mathrm{MeOH}$ to give $\mathbf{4 c}$ $(570 \mathrm{mg}, 68 \%)$ as an amorphous solid, $[\alpha]_{\mathrm{D}}^{23}+52.8^{\circ}(c=$ $\left.0.8, \mathrm{CHCl}_{3}\right)$; IR $v_{\max }^{\mathrm{KBr}} \mathrm{cm}^{-1}: 3450$ and $3290(\mathrm{OH}, \mathrm{NH})$, 2920 and $2850\left(\mathrm{CH}_{2}, \mathrm{CH}_{3}\right), 1635$ and 1530 (amide), and 720 and 690 (phenyl); NMR $\delta_{\mathrm{Me}_{4} \mathrm{Si}_{3}}^{\mathrm{CDCl}_{3}} 0.88\left(6 \mathrm{H}, 2 \mathrm{CH}_{3}\right), 1.27$ $\left(52 \mathrm{H}, 26 \mathrm{CH}_{2}\right), 1.45$ and $1.53\left(6 \mathrm{H}, 2 \mathrm{~s}, \mathrm{Me}_{2} \mathrm{C}\right), 3.04(1 \mathrm{H}, \mathrm{bs}$, $\mathrm{OH}), 4.48$ and $4.71\left(2 \mathrm{H}, 2 \mathrm{~d}, J_{\mathrm{gem}}=12.0 \mathrm{~Hz}, \mathrm{OCH}_{2} \mathrm{Ph}\right)$, $4.95\left(1 \mathrm{H}, \mathrm{d}, J_{1,2}=4.0 \mathrm{~Hz}, \mathrm{H}-1\right), 5.92\left(1 \mathrm{H}, \mathrm{d}, J_{2, \mathrm{NH}}=8.5 \mathrm{~Hz}\right.$, $\mathrm{NH})$, and $7.43(5 \mathrm{H}, \mathrm{s}, \mathrm{Ph})$. Anal. Found: C, 74.14; H, 10.93; N, 1.92. Calcd. for $\mathrm{C}_{46} \mathrm{H}_{81} \mathrm{NO}_{6}: \mathrm{C}, 74.24 ; \mathrm{H}, 10.97$; $\mathrm{N}, 1.88 \%$.

Benzyl 2-(benzyloxycarbonylamino)-3-O-(D-1carboxyethyl)-2-deoxy-4,6-O-isopropylidene- $\alpha-\mathrm{D}-$ glucopyranoside (5). To a stirred solution of $3(1.3 \mathrm{~g})$ in dry 1,4-dioxane $(10 \mathrm{ml})$ was gradually added sodium hydride in oil suspension $(560 \mathrm{mg} ; 50 \%$ of sodium hydride by weight), and the mixture was heated with stirring for $1 \mathrm{hr}$ at $90^{\circ} \mathrm{C}$. After being cooled to $60^{\circ} \mathrm{C}, \mathrm{L}$-2-chloropropanoic acid $(410 \mathrm{mg})$ was gradually added to the mixture and the final mixture was stirred for $5 \mathrm{hr}$ at $60^{\circ} \mathrm{C}$. After being cooled, $\mathrm{H}_{2} \mathrm{O}$ was added to the mixture to decompose the excess of sodium hydride, and then the $\mathrm{pH}$ of the mixture was adjusted to 3 with $2 \mathrm{M} \mathrm{HCl}$. The mixture was extracted with $\mathrm{CHCl}_{3}$ and the extract was washed with $\mathrm{H}_{2} \mathrm{O}$, dried $\left(\mathrm{Na}_{2} \mathrm{SO}_{4}\right)$, and evaporated to a syrup which was purified on a column of silica gel $(40 \mathrm{~g})$ with $100: 1 \mathrm{CHCl}_{3}-$ $\mathrm{MeOH}$. Compound 5 was obtained as a syrup, $890 \mathrm{mg}$ $(59 \%),[\alpha]_{\mathrm{D}}^{20}+87.3^{\circ}\left(c=0.6, \mathrm{CHCl}_{3}\right) ; \mathrm{IR} v_{\max }^{\mathrm{film}} \mathrm{cm}^{-1}: 3320$ (NH), 1710 (COOH), 1690 and 1520 (amide), 850 $\left(\mathrm{Me}_{2} \mathrm{C}\right)$, and 730 and 690 (phenyl); $\mathrm{NMR} \delta_{\mathrm{Me}_{4} \mathrm{Si}_{3}}^{\mathrm{CDCl}_{3}} 1.43$ $\left(3 \mathrm{H}, \mathrm{d}, J_{\mathrm{CH}_{3}, \mathrm{CH}}=7.0 \mathrm{~Hz}, \mathrm{CH}_{3}\right), 1.42$ and $1.51(6 \mathrm{H}, 2 \mathrm{~s}$, $\left.\mathrm{Me}_{2} \mathrm{C}\right), 5.13 \sim 5.20\left(3 \mathrm{H}, \mathrm{CO}_{2} \mathrm{CH}_{2} \mathrm{Ph}\right.$ and $\left.\mathrm{H}-1\right), 7.25 \sim$ $7.40(2 \mathrm{H}, \mathrm{COOH}$ and $\mathrm{NH})$ and $7.41(10 \mathrm{H}, \mathrm{s}, 2 \mathrm{Ph})$. Anal. Found: C, 62.64; H, 6.55; N, 2.85. Calcd. for $\mathrm{C}_{27} \mathrm{H}_{33} \mathrm{NO}_{9}$ : C, 62.90; H, 6.45; N, $2.72 \%$.

Benzyl 3-O-(D-1-carboxyethyl)-2-deoxy-4,6,-O-isopropylidene-2-(tetracosanoylamino $)-\alpha-\mathrm{D}-$ glucopyranoside $(\mathbf{6 b})$. Condensation of $\mathbf{4 b}(1.5 \mathrm{~g})$ with $\mathrm{L}$-2-chloropropanoic acid $(300 \mathrm{mg})$ according to the procedure as described above was performed. The product was purified by chromatography on a column of silica gel $(50 \mathrm{~g})$ with $100: 1 \mathrm{CHCl}_{3}-\mathrm{MeOH}$. Compound $\mathbf{6 b}$ was obtained as a syrup, $1.40 \mathrm{~g}(84 \%),[\alpha]_{\mathrm{D}}^{20}+67.2^{\circ}\left(c=0.5, \mathrm{CHCl}_{3}\right)$; IR $v_{\max }^{\mathrm{KBr}} \mathrm{cm}^{-1}: 3300(\mathrm{NH}), 2920$ and $2850\left(\mathrm{CH}_{2}, \mathrm{CH}_{3}\right)$,
$1710(\mathrm{COOH}), 1640$ and 1540 (amide), $850\left(\mathrm{Me}_{2} \mathrm{C}\right)$, and 720 and 690 (phenyl); NMR $\delta_{\mathrm{Me}_{4} \mathrm{Si}}^{\mathrm{CDCl}_{3}}: 0.90(3 \mathrm{H}$, $\left.\mathrm{CH}_{3}\right), 1.28\left(42 \mathrm{H}, 21 \mathrm{CH}_{2}\right), 1.44\left(3 \mathrm{H}, \mathrm{d}, J_{\mathrm{CH}_{3}, \mathrm{CH}}=7.0\right.$ $\mathrm{Hz}, \mathrm{CH}_{3}$ of propanoyl), 1.42 and $1.53\left(6 \mathrm{H}, 2 \mathrm{~s}, \mathrm{Me}_{2} \mathrm{C}\right)$, $5.38\left(1 \mathrm{H}, \mathrm{d}, J_{1,2}=2.8 \mathrm{~Hz}, \mathrm{H}-1\right), 7.40(5 \mathrm{H}, \mathrm{s}, \mathrm{Ph})$ and 7.58 (1H, bs, NH). Anal. Found: C, 70.43; H, 10.19; N, 1.90. Calcd. for $\mathrm{C}_{43} \mathrm{H}_{73} \mathrm{NO}_{8}$ : C, 70.55; H, $10.05 ; \mathrm{N}, 1.91 \%$.

Benzyl 3-O-(D-I-carboxyethyl)-2-deoxy-4,6-O-isopropylidene-2-(2-tetradecy!hexadecanoylamino)- $\alpha-\mathrm{D}-\mathrm{glu}$ copyranoside (6c). Condensation of $\mathbf{4 c}(520 \mathrm{mg})$ with L2-chloropropanoic acid $(100 \mathrm{mg})$ according to the method as described in the preparation of 5 afforded $\mathbf{6 c}(500 \mathrm{mg}$, $88 \%)$ as a syrup, $[\alpha]_{\mathrm{D}}^{23}+69.1^{\circ}\left(c=0.7, \mathrm{CHCl}_{3}\right)$. Anal. Found: $\mathrm{C}, 71.63 ; \mathrm{H}, 10.41 ; \mathrm{N}, 1.82$. Calcd. for $\mathrm{C}_{49} \mathrm{H}_{85} \mathrm{NO}_{8}$ : C, 72.10; H, 10.50; N, $1.72 \%$.

Benzyl 3-O-(D-1-carboxyethyl)-2-deoxy-2-(3-hydroxy2-tetradecyloctadecanoylamino )-4,6-O-isopropylidene- $\alpha$ D-glucopyranoside (6d). Compound 5 (130 mg) in $\mathrm{MeOH}$ $(8 \mathrm{ml})$ was hydrogenated in the presence of $10 \% \mathrm{Pd} / \mathrm{C}$ catalyst for $1 \mathrm{hr}$ at room temperature. The catalyst was removed off by filtration, and the filtrate was evaporated below $40^{\circ} \mathrm{C}$. To a solution of the residue in 1,4-dioxane (6 ml), $\quad N$-(3-hydroxy-2-tetradecyloctadecanoyloxy)succinimide ( $\left.\mathrm{mp} 73 \sim 74^{\circ} \mathrm{C}\right)(230 \mathrm{mg})$ and triethylamine $(0.1 \mathrm{ml})$ were added. The mixture was stirred overnight at room temperature. After removal of the solvents, the residue was chromatographed on a column of silica gel $(30 \mathrm{~g})$ with $100: 1 \mathrm{CHCl}_{3}-\mathrm{MeOH}$ to give $6 \mathbf{d}(150 \mathrm{mg}, 69 \%)$ as crystals, $\mathrm{mp} 149 \sim 150^{\circ} \mathrm{C},[\alpha]_{\mathrm{D}}^{20}+57.7^{\circ}(c=0.95$, $\left.\mathrm{CHCl}_{3}\right), \mathrm{IR} v_{\max }^{\mathrm{KBr}} \mathrm{cm}^{-1}: 3300(\mathrm{OH}, \mathrm{NH}), 2920$ and 2850 $\left(\mathrm{CH}_{2}, \mathrm{CH}_{3}\right), 1710(\mathrm{COOH}), 1635$ and 1550 (amide), 850 $\left(\mathrm{Me}_{2} \mathrm{C}\right)$, and 725 and 690 (phenyl); NMR $\delta_{\mathrm{Me}_{4} \mathrm{Si}_{3}}^{\mathrm{CDCl}_{3}}: 5.52$ $(1 \mathrm{H}, \mathrm{H}-1), 7.40(5 \mathrm{H}, \mathrm{s}, \mathrm{Ph})$ and $8.60 \sim 8.90(1 \mathrm{H}, \mathrm{COOH})$. Anal. Found: C, 71.41; H, 10.42; N, 1.71. Calcd. for $\mathrm{C}_{51} \mathrm{H}_{89} \mathrm{NO}_{9}$ : C, 71.20; $\mathrm{H}, 10.43 ; \mathrm{N}, 1.63 \%$.

Benzyl 3-O-(D-1-carboxyethyl)-2-deoxy-2-(3-hydroxy2-docosylhexacosanoylamino )-4,6-O-isopropylidene- $\alpha$-Dglucopyranoside (6e). Selective hydrogenolysis of the benzyloxycarbonyl group in $\mathbf{5}(400 \mathrm{mg})$ was carried out by the same way as described above. To a solution of the amino compound in 1,4-dioxane $(4 \mathrm{ml})$ were added $\mathrm{N}$ (3-hydroxy-2-docosylhexacosanoyloxy)succinimide (mp $\left.93 \sim 94^{\circ} \mathrm{C}\right)(700 \mathrm{mg})$ and triethylamine $(0.1 \mathrm{ml})$. The mixture was stirred for $20 \mathrm{hr}$ at room temperature, and then evaporated. The residue was chromatographed on a column of silica gel $(30 \mathrm{~g})$ with $200: 1 \mathrm{CHCl}_{3}-\mathrm{MeOH}$ to afford $6 \mathrm{e}(558 \mathrm{mg}, 66 \%)$ as a syrup, $[\alpha]_{\mathrm{D}}^{22}+55.0^{\circ}(c=0.8$, $\mathrm{CHCl}_{3}$ ). Anal. Found: C, 73.71, H, 11.33; N, 1.20. Calcd. for $\mathrm{C}_{67} \mathrm{H}_{121} \mathrm{NO}_{9}: \mathrm{C}, 74.19 ; \mathrm{H}, 11.24 ; \mathrm{N}, 1.29 \%$.

Benzyl 3-O-(D-1-carboxyethyl)-2-deoxy-4,6-O-isopropylidene-2-(mycoloylamino)- $\alpha$-D-glucopyranoside (6f). Selective hydrogenolysis of 5 (300 mg) was performed according to the procedure as described in the preparation 
of 6d. To a solution of the amino compound in 1,4dioxane $(3 \mathrm{ml})$ were added $N$-(mycoloyloxy)succinimide $^{11 \mathrm{c})}(600 \mathrm{mg})$ and triethylamine $(0.05 \mathrm{ml})$. The mixture was stirred for $48 \mathrm{hr}$ at room temperature, and then evaporated. The residue was chromatographed on a column of silica gel $(15 \mathrm{~g})$ with $100: 1 \mathrm{CHCl}_{3}-\mathrm{MeOH}$ to give $6 f(290 \mathrm{mg}, 49 \%), \mathrm{mp} 83 \sim 87^{\circ} \mathrm{C},[\alpha]_{\mathrm{D}}^{23}+34.8^{\circ}(c=$ 1.0, $\mathrm{CHCl}_{3}$ ). Anal. Found: C, 76.75; $\mathrm{H}, 11.84 ; \mathrm{N}, 1.13$. Calcd. for $\mathrm{C}_{99} \mathrm{H}_{183} \mathrm{NO}_{9.5}$ : C, 77.23; H, 11.98; N, 0.91\%.

Benzyl 2-deoxy-4,6-O-isopropylidene-3-O-(D-2-propanoyl-L-alanyl-D-isoglutamine benzyl ester)-2-tetracosanoylamino)- $\alpha$-D-glucopyranoside (7b). To a solution of $\mathbf{6 b}$ $(300 \mathrm{mg})$ in 1,4-dioxane $(5 \mathrm{ml})$ were added $N$-hydroxysuccinimide (HOSu) $(70 \mathrm{mg})$ and dicyclohexylcarbodiimide (DCC) $(110 \mathrm{mg}$ ), and the mixture was stirred for $2 \mathrm{hr}$ at $10^{\circ} \mathrm{C}$. 1,3-Dicyclohexylurea formed was removed by filtration. L-Alanyl-D-isoglutamine benzyl ester trifluoroacetate $^{17)}(210 \mathrm{mg})$ and triethylamine $(0.1 \mathrm{ml})$ were added to the filtrate, and the mixture was stirred for $4 \mathrm{hr}$ at room temperature, and then evaporated. The residue was chromatographed on a column of silica gel $(30 \mathrm{~g})$ with 100 $: 1$, and then $40: 1 \mathrm{CHCl}_{3}-\mathrm{MeOH}$. With the latter eluant, compound $7 \mathbf{b}$ was obtained, wt. $350 \mathrm{mg}(84 \%)$, mp $107 \sim 109^{\circ} \mathrm{C},[\alpha]_{\mathrm{D}}^{18}+61.6^{\circ} \quad\left(c=0.63, \mathrm{CHCl}_{3}\right):$ IR $v_{\max }^{\mathrm{KBr}}$ $\mathrm{cm}^{-1}: 3450$ and $3380(\mathrm{NH}), 2920$ and $2850\left(\mathrm{CH}_{2}, \mathrm{CH}_{3}\right)$ 1730 (ester), 1650 and 1530 (amide), $850\left(\mathrm{Me}_{2} \mathrm{C}\right)$, and 725 and 690 (phenyl); NMR $\delta_{\mathrm{Me}_{4} \mathrm{Si}_{3}}^{\mathrm{CDCl}_{3}} 4.93\left(1 \mathrm{H}, \mathrm{d}, J_{1,2}=3.8 \mathrm{~Hz}\right.$, $\mathrm{H}-1), 5.16\left(2 \mathrm{H}, \mathrm{s}, \mathrm{CO}_{2} \mathrm{CH}_{2} \mathrm{Ph}\right)$, and $7.42(10 \mathrm{H}, \mathrm{s}, 2 \mathrm{Ph})$. Anal. Found: C, 68.00; H, 9.00; N, 5.25. Calcd. for $\mathrm{C}_{58} \mathrm{H}_{92} \mathrm{~N}_{4} \mathrm{O}_{11}: \mathrm{C}, 68.20 ; \mathrm{H}, 9.08 ; \mathrm{N}, 5.49 \%$.

Other protected $N$-(acyl)muramoyl-L-alanyl-D-isoglutamines (7) were similarly prepared from the corresponding, protected $\mathrm{N}$-(acyl)muramic acid (6) and Lalanyl-D-isoglutamine benzyl ester.

Benzyl 2-deoxy-4,6-O-isopropylidene-3-O-(D-2-propanoyl-L-alanyl-D-isoglutamine benzyl ester)-2-(2-tetradecylhexadecanoylamino )- $\alpha$-D-glucopyranoside (7c). Yield $89 \%$, $\mathrm{mp} 133 \sim 134^{\circ} \mathrm{C},[\alpha]_{\mathrm{D}}^{22}+61.0^{\circ}\left(c=0.8, \mathrm{CHCl}_{3}\right)$. Anal. Found: $\mathrm{C}, 69.47 ; \mathrm{H}, 9.34 ; \mathrm{N}, \quad 5.05$. Calcd. for $\mathrm{C}_{64} \mathrm{H}_{104} \mathrm{~N}_{4} \mathrm{O}_{11}: \mathrm{C}, 69.53 ; \mathrm{H}, 9.48 ; \mathrm{N}, 5.07 \%$.

Benzyl 2-deoxy-2-(3-hydroxy-2-tetradecyloctadecanoylamino )-4,6-O-isopropylidene-3-O-(D-2-propanoyl-L-alanyl-D-isoglutamine benzyl ester)- $\alpha$-D-glucopyranoside (7d). Yield $79 \%, \mathrm{mp} 145 \sim 146^{\circ} \mathrm{C},[\alpha]_{\mathrm{D}}^{20}+54.2^{\circ}$ $\left(c=0.9, \mathrm{CHCl}_{3}\right)$. Anal. Found: C, 68.72; H, 9.52; N, 4.87. Calcd. for $\mathrm{C}_{66} \mathrm{H}_{108} \mathrm{~N}_{4} \mathrm{O}_{12}: \mathrm{C}, 68.95 ; \mathrm{H}, 9.47 ; \mathrm{N}$, $4.87 \%$.

Benzyl 2-deoxy-2-(3-hydroxy-2-docosylhexacosanoylamino )-4,6-O-isopropylidene-3-O-(D-2-propanoylL-alanyl-D-isoglutamine benzyl ester)- $\alpha$-D-glucopyranoside $(7 \mathrm{e})$. Yield $84 \%$, mp $121 \sim 122^{\circ} \mathrm{C},[\alpha]_{\mathrm{D}}^{22}+46.3^{\circ}(c=$ $0.8, \mathrm{CHCl}_{3}$ ). Anal. Found: C, 71.59; H, 10.20; N, 3.99.
Calcd. for $\mathrm{C}_{82} \mathrm{H}_{140} \mathrm{~N}_{4} \mathrm{O}_{12}: \mathrm{C}, 71.68 ; \mathrm{H}, 10.27 ; \mathrm{N}$, $4.08 \%$.

Benzyl 2-deoxy-4,6-O-isopropylidene-2-(mycoloylamino )-3-O-(D-2-propanoyl-L-alanyl-D-isoglutamine benzyl ester)- $\alpha$-D-glucopyranoside (7f). Yield $81 \%, \mathrm{mp}$ $87^{\circ} \mathrm{C},[\alpha]_{\mathrm{D}}^{23}+33.6^{\circ}\left(c=1.0, \mathrm{CHCl}_{3}\right)$. Anal. Found: $\mathrm{C}$, $74.86 ; \mathrm{H}, 11.32 ; \mathrm{N}, 2.80$. Calcd. for $\mathrm{C}_{114} \mathrm{H}_{202} \mathrm{~N}_{4} \mathrm{O}_{12.5}$ : C, $74.87 ; \mathrm{H}, 11.13 ; \mathrm{N}, 3.06 \%$.

$\mathrm{N}$-(3-Hydroxy-2-tetradecyloctadecanoyl) muramoyl-Lalanyl-D-isoglutamine (1d). A solution of $7 \mathbf{d}(90 \mathrm{mg})$ in $80 \%$ aqueous $\mathrm{AcOH}(5 \mathrm{ml})$ was heated for $2 \mathrm{hr}$ at $45^{\circ} \mathrm{C}$, and then evaporated. The residue was triturated with ethyl ether to give the diol derivative $(86 \mathrm{mg}, 99 \%)$, mp $169 \sim 172^{\circ} \mathrm{C},[\alpha]_{\mathrm{D}}^{20}+49.1^{\circ}(c=0.75, \mathrm{MeOH})$. The product $(75 \mathrm{mg})$ in a mixture of THF $(5 \mathrm{ml})$ and $\mathrm{AcOH}(1 \mathrm{ml})$ was hydrogenated in the presence of palladium black catalyst for $24 \mathrm{hr}$ at room temperature $\left(25^{\circ} \mathrm{C}\right)$. After removal of the catalyst and evaporation of the solvents, the residue was chromatographed on a column of silica gel $(15 \mathrm{~g})$ with $50: 1 \mathrm{CHCl}_{3}-\mathrm{MeOH}$ and 100:10:1 $\mathrm{CHCl}_{3}-\mathrm{MeOH}-$ $\mathrm{AcOH}$. The latter eluate afforded compound 1d $(59 \mathrm{mg}$, $83 \%$ ), mp $162 \sim 165^{\circ} \mathrm{C}$ (dec.), $[\alpha]_{\mathrm{D}}^{22}+11.3^{\circ}$ (after $24 \mathrm{hr}: c=$ $0.32, \mathrm{MeOH}) ; \mathrm{IR} v_{\max }^{\mathrm{KBr}} \mathrm{cm}^{-1}: 3350(\mathrm{OH}, \mathrm{NH}), 2920$ and $2850\left(\mathrm{CH}_{2}, \mathrm{CH}_{3}\right)$, and 1650 and 1550 (amide). Anal. Found: $\mathrm{C}, 61.89 ; \mathrm{H}, 10.11 ; \mathrm{N}$, 5.73. Calcd. for $\mathrm{C}_{49} \mathrm{H}_{92} \mathrm{~N}_{4} \mathrm{O}_{12} \cdot \mathrm{H}_{2} \mathrm{O}: \mathrm{C}, 62.12 ; \mathrm{H}, 10.00 ; \mathrm{N}, 5.91 \%$.

Other $N$-(acyl)muramoyl-L-alanyl-D-isoglutamines (1) were similarly prepared from the corresponding, protected muramoyl dipeptides (7).

$N$-(Tetracosanoyl) muramoyl-L-alanyl-D-isoglutamine (1b). mp $188 \sim 191^{\circ} \mathrm{C}$ (dec.), $[\alpha]_{\mathrm{D}}^{22}+16.1^{\circ}$ (after $24 \mathrm{hr}: c=$ 0.57, MeOH). Anal. Found: C, 61.00; H, 9.40; N, 6.64. Calcd. for $\mathrm{C}_{41} \mathrm{H}_{76} \mathrm{~N}_{4} \mathrm{O}_{11} \cdot 1 / 2 \mathrm{H}_{2} \mathrm{O}: \mathrm{C}, 69.79 ; \mathrm{H}, 9.58 ; \mathrm{N}$, $6.92 \%$.

$\mathrm{N}$-(2-Tetradecylhexadecanoyl) muramoyl-L-alanyl-Disoglutamine (1c). $\mathrm{mp} 163 \sim 165^{\circ} \mathrm{C}$ (dec.), $[\alpha]_{\mathrm{D}}^{22}+7.7^{\circ}$ (after $\left.24 \mathrm{hr}: c=0.6,1: 1 \mathrm{CHCl}_{3}-\mathrm{MeOH}\right)$. Anal. Found: C, 69.18; $\mathrm{H}, 11.15 ; \mathrm{N}, 6.61$. Calcd. for $\mathrm{C}_{47} \mathrm{H}_{88} \mathrm{~N}_{4} \mathrm{O}_{11} \cdot \mathrm{H}_{2} \mathrm{O}$ : C, 69.47; $\mathrm{H}, 11.17$; N, $6.90 \%$.

$N$-(3-Hydroxy-2-docosylhexacosanoyl) muramoyl-Lalanyl-D-isoglutamine (1e). $\mathrm{mp} 170^{\circ} \mathrm{C}(\mathrm{dec}),.[\alpha]_{\mathrm{D}}^{23}+6.3^{\circ}$ (after $24 \mathrm{hr}, c=0.38,1: 1 \mathrm{CHCl}_{3}-\mathrm{MeOH}$ ). Anal. Found: C, 66.88; $\mathrm{H}, 10.83 ; \mathrm{N}, 4.45$. Calcd. for $\mathrm{C}_{65} \mathrm{H}_{124} \mathrm{~N}_{4} \mathrm{O}_{12}$. $\mathrm{H}_{2} \mathrm{O}: \mathrm{C}, 66.63 ; \mathrm{H}, 10.84 ; \mathrm{N}, 4.78 \%$.

$N$-( Mycoloyl) muramoyl-L-alanyl-D-isoglutamine (1f). mp $169 \sim 170^{\circ} \mathrm{C}$ (dec.), $[\alpha]_{\mathrm{D}}^{22}+2.0^{\circ}$ (after $24 \mathrm{hr}: c=1.0$, $\mathrm{CHCl}_{3}$ ). Anal. Found: C, 69.62; H, 11.26; N, 2.98. Calcd. for $\mathrm{C}_{97} \mathrm{H}_{186} \mathrm{~N}_{4} \mathrm{O}_{12.5} \cdot 3 \mathrm{H}_{2} \mathrm{O}: \mathrm{C}, 70.07 ; \mathrm{H}, 11.64 ; \mathrm{N}, 3.37 \%$.

Benzyl 2-acetamido-2,6-dideoxy-6-(3-hydroxy-2- 
docosylhexacosanoylamino)-3-O-(D-2-propanoyl-Lalanyl-D-isoglutamine benzyl ester)- $\alpha$-D-glucopyranoside (9A). To a solution of $\mathbf{8} \mathbf{A}^{11)}(200 \mathrm{mg})$ in a mixture of $\mathrm{MeOH}(10 \mathrm{ml})$ and THF $(5 \mathrm{ml})$ was added Raney-nickel catalyst (W-1), and the mixture was stirred overnight at room temperature. After removal of the catalyst and evaporation of the solvents, the residue was dissolved in THF $(5 \mathrm{ml})$, and $N$-(3-hydroxy-2-docosylhexacosanoyloxy)succinimide $(345 \mathrm{mg})$ was added. The mixture was stirred for $48 \mathrm{hr}$ at room temperature, and then evaporated. The residue was chromatographed on a column of silica gel $(50 \mathrm{~g})$ with $\mathrm{CHCl}_{3}$ and $50: 1 \mathrm{CHCl}_{3}-$ $\mathrm{MeOH}$. With the latter eluant, compound 9A (200 mg, $51 \%$ ) was obtained, $\mathrm{mp} 216 \sim 218^{\circ} \mathrm{C}$ (dec.), $[\alpha]_{\mathrm{D}}^{22}+45.8^{\circ}$ $\left(c=0.8,1: 1 \mathrm{CHCl}_{3}-\mathrm{MeOH}\right) ; \mathrm{IR} v_{\max }^{\mathrm{KBr}} \mathrm{cm}^{-1}: 3400$ and $3270(\mathrm{OH}, \mathrm{NH}), 2920$ and $2850\left(\mathrm{CH}_{2}, \mathrm{CH}_{3}\right), 1730$ (ester), 1653 and 1540 (amide), and 720 and 690 (phenyl). Anal. Found: $\mathrm{C}, 70.27 ; \mathrm{H}, \quad 9.99 ; \mathrm{N}, \quad 5.06$. Calcd. for $\mathrm{C}_{81} \mathrm{H}_{139} \mathrm{~N}_{5} \mathrm{O}_{12}: \mathrm{C}, 70.75 ; \mathrm{H}, 10.19 ; \mathrm{N}, 5.09 \%$.

Benzyl 2-acetamido-2,6-dideoxy-6-(3-hydroxy-2docosylhexacosanoylamino)-3-O-(D-2-propanoyl-L-valylD-isoglutamine benzyl ester)- $\alpha$-D-glucopyranoside (9B). Selective reduction of the azide group in $\mathbf{8} \mathbf{B}^{11)}(200 \mathrm{mg})$, and subsequent coupling with the active ester $(360 \mathrm{mg})$, as described for the preparation of $\mathbf{9 A}$, gave the product, which was purified by chromatography on a column of silica gel $(30 \mathrm{~g})$ with $100: 1$, and $20: 1 \mathrm{CHCl}_{3}-\mathrm{MeOH}$. The latter eluate gave compound 9B (173 mg, 45\%), mp $205 \sim 207^{\circ} \mathrm{C}$ (dec.), $[\alpha]_{\mathrm{D}}^{22}+29.7^{\circ}\left(c=0.35,1: 1 \mathrm{CHCl}_{3}-\right.$ $\mathrm{MeOH})$. Anal. Found: C, 70.83; H, 10.06; N, 4.90. Calcd. for $\mathrm{C}_{83} \mathrm{H}_{143} \mathrm{~N}_{5} \mathrm{O}_{12}$ : C, 71.05; $\mathrm{H}, 10.27 ; \mathrm{N}, 4.99 \%$.

Benzyl 2-acetamido-2,6-dideoxy-6-(3-hydroxy-2docosylhexacosanoylamino)-3-O-(D-2-propanoyl-O-ben$z y$-L-seryl-D-isoglutamine benzyl ester)- $\alpha$-D-glucopyranoside $(\mathbf{9 C})$. Selective reduction of the azide group in $\mathbf{8} \mathbf{C}^{11)}$ (150 mg), and subsequent coupling with the active ester $(200 \mathrm{mg})$, according to the procedure described in the previous section, gave the product which was purified by chromatography on a column of silica gel $(30 \mathrm{~g})$ with $100: 1$ and $20: 1 \mathrm{CHCl}_{3}-\mathrm{MeOH}$. With the latter eluant, compound $9 \mathrm{C}\left(85 \mathrm{mg}, 31 \%\right.$ ) was obtained, $\mathrm{mp} 215 \sim 217^{\circ} \mathrm{C}$ (dec.), $[\alpha]_{\mathrm{D}}^{22}+41.3^{\circ}\left(c=0.77,1: 1 \mathrm{CHCl}_{3}-\mathrm{MeOH}\right)$. Anal. Found: C, 71.02; H, 9.75; N, 4.66. Calcd. for $\mathrm{C}_{88} \mathrm{H}_{145} \mathrm{~N}_{5} \mathrm{O}_{13}: \mathrm{C}, 71.36 ; \mathrm{H}, 9.87 ; \mathrm{N}, 4.73 \%$.

$N$-Acetyl-6-deoxy-6-(3-hydroxy-2-docosylhexacosanoylamino) muramoyl-L-alanyl-D-isoglutamine (2A). Compound 9A $(180 \mathrm{mg})$ was hydrogenated, in the presence of palladium black catalyst, in a mixture of THF $(8 \mathrm{ml})$ and AcOH $(2 \mathrm{ml})$, for $24 \mathrm{hr}$ at $30^{\circ} \mathrm{C}$. After removal of the catalyst and evaporation of the solvents, the product was purified by chromatography on a column of silica gel $(20 \mathrm{~g})$ with $50: 1 \mathrm{CHCl}_{3}-\mathrm{MeOH}$ and 100:10:1 $\mathrm{CHCl}_{3}-\mathrm{MeOH}-\mathrm{AcOH}$. The latter eluate gave compound $2 \mathrm{~A}(155 \mathrm{mg}, 90 \%), \mathrm{mp} 175 \sim 177^{\circ} \mathrm{C}(\mathrm{dec}),.[\alpha]_{\mathrm{D}}^{22}$ $+11.6^{\circ}$ (after 24hr: $c=0.5,1: 1 \mathrm{CHCl}_{3}-\mathrm{MeOH}$ ); IR $v_{\max }^{\mathrm{KBr}}$ $\mathrm{cm}^{-1}: 3380(\mathrm{OH}, \mathrm{NH}), 2920$ and $2850\left(\mathrm{CH}_{2}, \mathrm{CH}_{3}\right)$ and 1640 and 1540 (amide). Anal. Found: C, 65.76; H, 10.32; $\mathrm{N}$, 5.39. Calcd. for $\mathrm{C}_{67} \mathrm{H}_{127} \mathrm{~N}_{5} \mathrm{O}_{12} \cdot 2 \mathrm{H}_{2} \mathrm{O}: \mathrm{C}, 65.38 ; \mathrm{H}$, $10.73 ; \mathrm{N}, 5.69 \%$.

N-Acetyl-6-deoxy-6-(3-hydroxy-2-docosylhexacosanoylamino) muramoyl-L-valyl-D-isoglutamine (2B). Hydrogenolysis of 9B ( $35 \mathrm{mg}$ ) was performed according to the same way as described above, affording 2B $\left(20 \mathrm{mg}, 66^{\circ}\right), \mathrm{mp} 172 \sim 174^{\circ} \mathrm{C}$ (dec.), $[\alpha]_{\mathrm{D}}^{22}+5.3^{\circ}$ (after $24 \mathrm{hr}: \quad c=0.15, \quad 1: 1 \quad \mathrm{CHCl}_{3}-\mathrm{MeOH}$ ). Anal. Found: $\mathrm{C}, 67.41 ;{ }^{\prime} \mathrm{H}, 10.98 ; \mathrm{N}, 5.50$, Calcd. for $\mathrm{C}_{69} \mathrm{H}_{131} \mathrm{~N}_{5} \mathrm{O}_{12}: \mathrm{C}, 67.77 ; \mathrm{H}, 10.80 ; \mathrm{N}, 5.73 \%$.

N-Acetyl-6-deoxy-6-(3-hydroxy-2-docosylhexacosanoylamino) muramoyl-L-seryl-D-isoglutamine (2C). Hydrogenolysis of 9C $(75 \mathrm{mg})$ was carried out according to the procedure described in the previous section, affording $2 \mathrm{C}(59 \mathrm{mg}, 96 \%), \mathrm{mp} 177 \sim 180^{\circ} \mathrm{C}$ (dec.), $[\alpha]_{\mathrm{D}}^{22}+7.0^{\circ}$ (after $24 \mathrm{hr}: c=0.4,1: 1 \mathrm{CHCl}_{3}-$ $\mathrm{MeOH})$. Anal. Found: C, 65.11; H, 10.33; N, 5.38. Calcd. for $\mathrm{C}_{67} \mathrm{H}_{127} \mathrm{~N}_{5} \mathrm{O}_{13} \cdot \mathrm{H}_{2} \mathrm{O}$ : C, 65.49; $\mathrm{H}, 10.58 ; \mathrm{N}, 5.70 \%$.

Biological assay. Determination of adjuvant activity on the induction of delayed-type hypersensitivity and suppression test of transplantable tumor in syngeneic mice were carried out according to the methods reported previously. ${ }^{16)}$

\section{REFERENCES}

1) M. Kiso, Y. Goh, E. Tanahashi, A. Hasegawa, H. Okumura and I. Azuma, Carbohydr. Res., 90, C8 (1981).

2) F. Ellouz, A. Adam, R. Ciorbaru and E. Lederer, Biochem. Biophys. Res. Commun., 59, 1317 (1974).

3) S. Kotani, I. Morisaki, Y. Watanabe, F. Kinoshita, T. Shimono, T. Shiba, S. Kusumoto, Y. Tarumi and K. Ikenaka, Biken J., 18, 105 (1975).

4) E. Lederer, J. Med. Chem., 23, 819 (1980).

5) A. Adam, M. Devys, V. Souvannavong, P. Lefrancier, C. Choay and E. Lederer, Biochem. Biophys. Res. Commun., 72, 339 (1976).

6) S. Kotani, Y. Watanabe, F. Kinoshita, I. Morisaki, K. Kato, T. Shiba, S. Kusumoto, T. Tarumi and K. Ikenaka, Biken J., 20, 39 (1977).

7) I. Azuma, K. Kamisango, I. Saiki, Y. Tanio, S. Kobayashi and Y. Yamamura, Infect. Immun., 29, 1193 (1980).

8) A. Hasegawa, K. Kaneda, M. Amano, M. Kiso and I. Azuma, Agric. Biol. Chem., 42, 2187 (1978).

9) M. Kiso, Y. Kaneda, Y. Goh, A. Hasegawa and I. Azuma, Agric. Biol. Chem., 44, 1971 (1980).

10) M. Kiso, Y. Kaneda, H. Okumura, A. Hasegawa, I. Azuma and Y. Yamamura, Carbohydr. Res., 79, C17 (1980). 
11) (a) A. Hasegawa, H. Okumura, M. Kiso, I. Azuma and Y. Yamamura, Carbohydr. Res., 79, C20 (1980); (b) A. Hasegawa, H. Okumura, M. Kiso, I. Azuma and Y. Yamamura, Agric. Biol. Chem., 44, 1301 (1980); and (c) A. Hasegawa, H. Okumura, M. Kiso, I. Azuma and Y. Yamamura, Agric. Biol. Chem., 44, 1309 (1980).

12) I. Azuma, H. Okumura, I. Saiki, Y. Tanio, M. Kiso, A. Hasegawa and Y. Yamamura, Infect. Immun., 32, 1305 (1981).

13) I. Azuma, H. Okumura, I. Saiki, Y. Tanio, M. Kiso, A. Hasegawa and Y. Yamamura, Infect. Immun., 33,
834 (1981).

14) T. Shiba, S. Okada, S. Kusumoto, I. Azuma and Y. Yamamura, Bull. Chem. Soc. Jpn., 51, 3307 (1978).

15) S. Kusumoto, M. Inage, T. Shiba, I. Azuma and Y. Yamamura, Tetrahedron Lett., 4899 (1979).

16) I. Saiki, Y. Tanio, M. Yamawaki, M. Uemiya, S. Kobayashi, T. Fukuda, H. Yukimasa, Y. Yamamura and I. Azuma, Infect. Immun., 31, 114 (1981).

17) S. Kobayashi, T. Fukuda, H. Yukimasa, M. Fujino, I. Azuma and Y. Yamamura, Bull. Chem. Soc. Jpn., 53, 2570 (1980). 